\title{
DECIFRA-ME OU TE DEVORO! AS FINANÇAS E A SOCIEDADE BRASILEIRA
}

Roberto Grün

\section{Os enigmas e os períodos}

Um observador externo da cena brasileira do início do século XXI provavelmente ficaria surpreso com os termos do debate público no período. Numa região conhecida pelo peso das oligarquias, aparece um Presidente da República de origem operária, e eleito por um partido que reivindica uma tradição de acentuado cunho esquerdista. Durante a campanha eleitoral que acabou por elegê-lo, ele foi acusado com insistência de estar semeando o caos financeiro e, uma vez tendo tomado posse, simetricamente acusado de lançar uma política econômica de continuidade da ortodoxia anterior. Nessa rubrica, fez-se seguidor de um rigoroso plano de ajuste financeiro das contas públicas, mesmo sabendo que tal desiderato impede o crescimento econômico gerador de empregos, além de políticas sociais mais ambiciosas.

Num outro plano, nosso observador certamente repararia no enorme espaço que o banqueiro Daniel Dantas ocupa na mídia brasileira, não só na especializada em economia, mas também na política e mesmo na policial. ${ }^{1}$ Se versado em economia, ele procuraria as estatísticas setoriais e verificaria que seu banco, o Opportunity, não é dos maiores e se indagaria sobre as razões da evidência do personagem. Se mais atento aos fatos políticos, notaria que ele é acusado de estar por trás de um elenco tão grande e variado de cabalas, que desconfiaria da presença de algum elemento ficcional nas narrativas que o colocam no centro dos acontecimentos. E verificando que a ficção é tão disseminada, inferiria que ela fornece molduras e conteúdos adequados para os brasileiros expressarem suas impressões sobre a situação em que vivem.

Ao unir os dois planos, pretendo mostrar que eles podem ser articulados em torno da hipótese de que o Brasil vive no início do século XXI a instauração de um modo de dominação financeiro. Mais do que um simples 
Money talks, estamos diante da dominação cultural das finanças, que impõem a proeminência das suas maneiras de enxergar a realidade brasileira e enquadrar os problemas do país. E se a "doxa" não for suficiente para manter a sociedade brasileira no caminho apregoado, a violência econômica da arbitragem financeira - a especulação desenfreada contra os ativos financeiros brasileiros — nos abriga a voltar para a direção que a lógica financeira considera ser a única razoável.

Se versado em história econômica, nosso observador dificilmente deixaria de se perguntar por que o Brasil, país que se notabilizou por apresentar as taxas de crescimento econômico mais altas dos primeiros 70 anos do século $\mathrm{XX}$, permitiu-se aceitar nos últimos 25 anos os estreitos limites de crescimento que as finanças consideram ser os razoáveis (Salomão 2003). Meu ponto é que a resposta a essa indagação está fora dos limites explicativos da Economia. Podemos responder ao enigma lançando mão de uma periodização dos impensados culturais da sociedade brasileira dos últimos 30 anos, que a levam a naturalizar a situação econômica pela qual ela passa.

A periodização é dinâmica. Ela é o resultado, contingente, mas naturalizado, de uma guerra cultural que atravessa a sociedade brasileira. Em termos teóricos, ela pode ser entendida como uma expressão do conflito cultural, presente nas sociedades capitalistas atuais, instadas a adotar o "neoliberalismo", pelo estabelecimento de novas convenções cognitivas e pelas tentativas de alterar os seus contornos (Douglas 1986; Douglas et alii 1992; Douglas 1996; Lakoff 1996; Bourdieu 1997). Um elemento essencial da trama é que essa guerra não é bem percebida, uma vez que suas linhas de força não são redutíveis às disputas políticas explícitas, através das quais os observadores costumam enquadrar os contenciosos da sociedade. Por causa dessa peculiaridade, as constelações de atores e de interesses que se formam e desmancham, produzindo mais freqüentemente homologias, mas também coalizões passageiras, são pouco visíveis, contribuindo para a sua naturalização.

Na sua face econômica visível, a periodização que proponho começa nos anos 1970, com o auge do milagre econômico brasileiro, seguido da crise econômica do final dos anos 1970. Registro a edição da série de reporta-

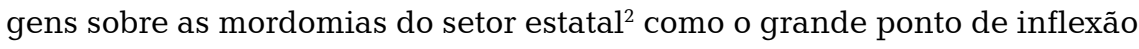
desse momento T(1). Antes, o Brasil vivia a euforia do milagre econômico. Naquele período, o protótipo do bom empreendimento era a grande empresa, multinacional, nacional ou estatal (Evans 1979). E no seio delas, os administradores profissionalizados, que planificavam suas ações, eram a base da racionalidade (Pereira 1974). A administração da economia deveria funcionar analogamente e ali o protótipo da eficiência era o planejamento econômico. 
Os Planos Nacionais de Desenvolvimento (PNDs), produzidos pela "tecnoburocracia" estatal, forneciam as molduras que balizavam as estratégias das grandes empresas. A antítese desse bloco era a pequena empresa na qual, segundo a representação da época, reinava a irracionalidade, a anarquia da indiferenciação entre a esfera da família e a da empresa, o desperdício e o nepotismo na escolha dos dirigentes (Durand et alii 1979). Na primeira fase da inflexão, o "antes", a grande empresa era a portadora do progresso e a pequena, um resíduo do passado. No "depois", a grande empresa estatal, um dos eixos do famoso tripé do desenvolvimento da época, começou a ser questionada e ganhou a pecha de "elefante branco": grande e vistoso, mas ineficiente (Grün 1999).

O segundo momento da cronologia - T(2) - apareceu quando o então Presidente Fernando Collor declarou que os automóveis brasileiros eram carroças, ${ }^{3}$ dizendo implicitamente que a indústria brasileira em sua integralidade era ineficiente e atrasada, e que seus gestores estavam acomodados a um ambiente econômico protegido, tudo isso à custa dos consumidores. Ao inverter um entendimento básico, importar passou a ser a solução. Dali em diante, o problema da economia brasileira não se faria presente somente na empresa estatal, mas todas as grandes empresas do país seriam responsáveis pelo atraso e o marasmo econômicos. Finalmente, durante a primeira quadra de FHC, o próprio conceito de organização passa a ser conotado negativamente, sendo contraposto às idéias de rede e de projeto (Boltanski e Chiapello 1999; Powell 2001). Qualquer organização impunha freios à atividade empreendedora dos indivíduos e de suas coalizões eventuais. O indivíduo tornou-se soberano. No espaço empresarial, é o período da privatização das companhias estatais e da drástica reorganização das empresas privadas no sentido da busca da lean organization - a empresa sem burocracia. A campanha publicitária falando da "gente que faz", veiculada por um grande banco de propriedade de um apoiador de primeira hora de FHC, bem como os interessantes prefácios do então Presidente da República e de sua esposa a dois volumes da principal obra sociológica de divulgação da idéia de rede no período registram e sustentam a hipótese (Castells 1999, 2002, 2005).

O Brasil entrou assim no período T(3) da cronologia que proponho.

\section{Mercado contra hierarquia}

Se examinarmos a seqüência $[\mathrm{T}(1) \rightarrow \mathrm{T}(2) \rightarrow \mathrm{T}(3)]$ acima a partir da conhecida contraposição "mercado x hierarquia" de Weber (1995), notaremos que ela indica um crescendo de positividade para a noção de mercado, e de negatividade para 
seu oposto, a idéia de hierarquia. Mas o contencioso cultural que tento recuperar inicialmente a partir da esfera econômica não se resolve nela. Voltemos ao nosso $\mathrm{T}(1)$ : o conjunto de reportagens que marcou o início da nossa periodização foi publicado no cotidiano mais identificado com o empresariado paulista tradicional, mas foi o resultado da pesquisa e da redação de um jornalista importante e identificado claramente com a esquerda do espectro político. Sua recepção no Brasil da época foi o resultado desse cruzamento de legitimidades.

O termo "mordomia" entrou no vocabulário do português falado no Brasil e permanecia lá 30 anos depois. ${ }^{4}$ Empresários e militantes da esquerda eram inimigos do status quo que sustentava as mordomias e ambos utilizaram aquele termo nas estratégias discursivas que visavam desacreditar o governo federal da época, visto como autoritário e hipertrofiado. Se seguirmos o padrão retórico descrito por Boltanski (1984), o mote das mordomias servia para os dois grupos de atores mostrarem que os representantes do status quo, quando diziam perseguir o interesse geral da nação, estavam na verdade buscando seus mesquinhos interesses individuais. Para os empresários, o Estado invadia ramos de negócios e áreas de regulação que deveriam estar sob o controle do empresariado privado. Para os militantes, o Estado impedia a expressão da sociedade civil que começava a entrar em ebulição. Os objetivos dos dois grupos eram distintos, mas ambas as estratégias discursivas passavam fundamentalmente por criar uma oposição entre o Estado: "grande/pesado/lento/desperdiçador/obsoleto/autoritário", e as organizações não-estatais, tidas como: "enxutas/leves/rápidas/econômicas/racionais".

No momento $\mathrm{T}(2)$, a argumentação dirigida contra as burocracias em geral também se nutria daquele que sustentava o desenvolvimento das Organizações Não-Governamentais (ONGs). O alvo na esfera econômica era então a empresa "excessivamente burocratizada" e na esfera política era o "Estado excessivamente burocratizado". A primeira não conseguiria se adaptar ao contexto econômico da globalização e o segundo não seria capaz de prover os serviços sociais necessários à população do país. No momento $\mathrm{T}(3)$, novamente o "indivíduo que faz", originalmente referido a iniciativas na esfera da intervenção social, torna a servir de modelo de excelência para a esfera econômica, que passa a exaltar a figura do empreendedor (referência Bamerindus) (Pereira 2006).

Como vemos, a nossa seqüência temporal $[\mathrm{T}(1) \rightarrow \mathrm{T}(2) \rightarrow \mathrm{T}(3)]$ não representa simplesmente a evolução ou a aclimatação no Brasil de novas idéias estritamente econômicas. Mais que isso, trata-se de um vetor bem definido no sentido de afirmar uma mudança na polaridade das categorias básicas de percepção, conduzindo à preponderância do "pequeno" sobre o "grande", da "espontaneidade" sobre o "planejamento". Só a partir desse 
pano de fundo é que podemos ancorar a noção de que "mercado" é uma forma de coordenação (espontânea) melhor do que a "hierarquia" (planejada, $\log o$, forçada). Analiticamente, essa peculiaridade produz o efeito da "obra sem mestre" - sendo, como vimos acima, o resultado de estratégias políticas e discursivas independentes provenientes de diversos grupos de agentes sem ligações diretas, a nova convenção cognitiva ganha naturalidade, desaparecendo o rastro da disputa cultural da qual ela é o resultado. A mudança geral de sensibilidades que ela produz dá-lhe a característica de uma revolução simbólica (Schorske 1979; Bourdieu 1992). Esta se instaura através de violências simbólicas que quanto mais intensas são, menos perceptíveis se mostram, já que elas calam os seus objetos e legitimam os seus sujeitos. Foi assim que, por exemplo, o não tão distante esforço público e privado associado à tentativa de desenvolvimento da indústria informática brasileira desapareceu das memórias, a não ser como modelo de quixotismo a ser exorcizado. Os cientistas, os engenheiros e os demais tecnólogos que a promoveram foram totalmente esquecidos e remoem suas mágoas sem poderem expressá-las, enquanto os economistas e os financistas que os denunciaram tornaram-se intérpretes do bom senso. ${ }^{5}$

O próximo passo da trama é a associação dos mercados financeiros às virtudes presumidas da idéia de mercado. Não se trata de uma conexão evidente, em primeiro lugar, por causa da associação persistente da imagem dos mercados financeiros à dos cassinos e demais jogos de azar. Aí podemos observar estratégias explícitas de diversos atores inseridos na esfera financeira, no sentido de alterar a percepção tradicional. Por exemplo, segundo Raymundo Magliano, então Presidente da Bolsa de Valores de São Paulo (Bovespa), para que o nosso mercado de capitais se desenvolva: "O fundamental é a mudança cultural na imagem da Bovespa. A bolsa era vista como um cassino, era uma caixa preta, uma casa de jogos. E, hoje, as pessoas falam em investir" (Pavini 2004). Nesse sentido, creio que analisar a construção da imagem pública de alguns atores exemplares através da associação que deles se faz aos problemas imputados ao predomínio da lógica financeira seja uma boa maneira de verificar o contencioso cultural que exponho. Poderíamos citar dentre eles: Naji Nahas, tido como um "mega-especulador" que causa graves danos à imagem do mercado financeiro brasileiro; Armínio Fraga, ex-presidente do Banco Central (1999-2002), acusado freqüentemente de ser o braço do financista/especulador internacional Georges Soros; Daniel Dantas, o novo banqueiro, cuja imagem parece se conformar com mais nitidez à figura tradicional do "plutocrata"; finalmente, Antônio Ermírio de Moraes, tido como o principal empresário inimigo do predomínio das finanças e voz daqueles que tentam diminuir a força de tal tendência. 


\section{O caminho das inovações financeiras}

Outra forma de perscrutar a influência das finanças na sociedade brasileira é o acompanhamento da difusão de inovações financeiras no país, quem as patrocina e as inflexões que elas sofrem ao se enraizarem no Brasil. O caso da governança corporativa é talvez o mais expressivo. Primeiro, por representar uma transformação significativa da noção de empresa e de organização em geral (Hirsch 2006). Segundo, por se nutrir da legitimidade de valores construídos na esfera cívica (Joseph 2005). Terceiro, porque posteriormente, como resultado de uma intensa atividade de legitimação promovida por diversos grupos de agentes ligados ao mercado financeiro, de consultoria e acadêmicos, ela foi abraçada por setores expressivos das elites não-financeiras da sociedade. E, finalmente, por mostrar a capacidade de subsumir diversas causas e preocupações desses últimos setores. Dessa maneira, a análise da "carreira" da governança corporativa no Brasil pode ser considerada uma boa entrada para entender as formas de penetração da lógica financeira em diversas esferas da sociabilidade do país. A outra "prova do pudim" do predomínio financeiro são as persistentes altas taxas de juros praticadas na economia brasileira (Cruz 2006). Ela pode ser analisada a partir da disseminação de uma espécie de "sabedoria convencional" à Galbraith (1998) ao dizer que no Brasil as taxas de juros devem, naturalmente, ser altas.

O resultado palpável da presença das duas tendências é que a distribuição de renda no seio da sociedade tende a privilegiar a fatia dos rentistas em detrimento daqueles que extraem o essencial de seus rendimentos do próprio trabalho. Tudo se passa como se a população brasileira estivesse se pensando como rentista. A complexidade do domínio das finanças fica patente nesse aparente paradoxo. As taxas de juros "naturalmente altas" vigentes no Brasil são sustentadas publicamente como uma decorrência da falta de marcos jurídicos e institucionais, a chamada tese "jurisdicional" (Haddad 2003). Os credores da sociedade brasileira dizem-se inseguros quanto à capacidade das suas instituições obrigarem os devedores, inclusive os governos, a pagarem suas dívidas e, por isso, seriam forçados a cobrar muito mais pelo crédito que adiantam.

Bem além da "falsicabilidade" dessa hipótese, salta aos olhos o seu imenso poder metafórico. No país do "jeitinho", essa idéia compõe fácil os estereótipos presentes na cultura popular com a "pouca seriedade" das instituições brasileiras (Duarte 2006). Aquela característica imputada à sociedade brasileira entra facilmente em seqüência mnemônica com a "hipótese" jurisdicional, que a reitera. Cria-se uma espiral de verossimilhança mútua, 
que produz a não-estranheza, a familiaridade e, finalmente, a aceitação tanto da versão popular quanto da erudita. ${ }^{6} \mathrm{O}$ resultado dessa configuração é a aceitação de que o pecado da "bagunça/insegurança institucional" deve ser purgado pela autoflagelação das taxas de juros mais elevadas da face da Terra. E, assim, ao mesmo tempo em que defendem os interesses do setor financeiro, economistas e demais anunciadores dessa versão, na sua maior parte figuras ligadas àquele espaço, vão também ocupando uma das funções primordiais do intelectual: a de enunciar as características fundamentais através das quais a sociedade brasileira deve ser percebida e representada.

Mas a força dos argumentos não explica diretamente os resultados tão favoráveis ao setor financeiro. Há evidentemente outras formas de representar a sociedade brasileira, seus problemas e virtudes. O incontornável é que a visão financista se impôs como o resultado provisório, mas palpável, da guerra cultural que atravessa a sociedade brasileira. No início, essa guerra foi travada no terreno da atividade produtiva, gerando o efeito de desestruturar a visão de mundo e a capacidade de defesa de atores típicos da ordem industrial, que passa a ser submetida à ordem financeira (Grün 1999). Em seguida, as razões das finanças cooptaram diversos segmentos das elites nacionais, inclusive aquelas que venceram as eleições presidenciais de 2002, que passam a se expressar a partir de seus argumentos e a utilizar os seus instrumentos, tanto os cognitivos quanto os econômicos (Grün 2005b).

A configuração simbólica mostra os limites do espaço cognitivo que produz os resultados acima (Fauconnier 1999; Bourdieu 2002). Como conseqüência da guerra cultural, as razões das finanças são tacitamente acatadas, ganham muito rápido o estatuto de "interesse geral da nação" e dificilmente são desbancadas. Já os argumentos oriundos de outros segmentos são descartados, a princípio, por serem considerados as manifestações de interesses particulares de grupos, os quais se contrapõem aos interesses gerais da nação. Dessa maneira, qualquer iniciativa no sentido da implantação de uma política industrial é considerada "corporativa", e descartada.

\section{O campo financeiro}

A questão do spread bancário pode servir de exemplo para ilustrar o assunto. Em primeiro lugar, porque ele é a forma básica de remuneração do setor financeiro. Em seguida, porque os atores econômicos não-financeiros identificam nele a principal razão da assimetria de rendimentos que desacelera a economia brasileira. Da escola da regulação ao Fundo Monetário Internacional 
(Bautzer 2005), passando por Delfim Netto (2004), pela quase totalidade dos interessados não-banqueiros (Carvalho 2004), e mesmo pelos políticos petistas e os assessores palacianos sem responsabilidade direta pelo setor financeiro (Romero 2004), os economistas não diretamente comprometidos com o sistema financeiro culpam a oligopolização do crédito por esse problema considerado central na economia brasileira. Mas as medidas governamentais mais expressivas do grupo - no poder durante o período petista - para lidar com o problema são respostas às queixas dos atuais banqueiros. Estes alegam dificuldades na imposição fiscal e na esfera legal com a recuperação dos créditos duvidosos para justificar o atual custo do dinheiro. A agenda é assim saturada por questões como a da necessidade de desoneração fiscal nas aplicações financeiras, a de uma nova lei das falências, a de maior rapidez na execução de garantias de crédito e a de outras inovações na esfera processual. Portanto, não é por acaso que a discussão da assimetria entre o sistema bancário e seus usuários nem chega a se estabelecer.

Num outro plano, se olharmos para o interior do mundo das finanças, há diferenças de grau nas justificativas para os juros altos. Elas são altamente indiciárias para a análise sociológica, pois revelam a estrutura social interna daquele espaço. Quando aflora a questão-chave, ao mesmo tempo prática e ideológica, do spread bancário (taxa de intermediação calculada como a diferença entre a taxa que os bancos pagam aos aplicadores e a que cobram dos devedores) e do significado das altas taxas de juros praticadas pela banca nacional, podemos notar um contencioso geracional. Ele se manifesta no contraste entre tomadas públicas de posição dos responsáveis pela Febraban, que representa a parcela "estabelecida" das finanças, e posições de indivíduos que configuram o novo padrão dos bancos de atacado e de investimentos que surgiram nos últimos anos. As altas taxas são consideradas "naturais" pelos novos entrantes, que culpam a cultura e a sociedade brasileiras que prefeririam a incerteza, tendo o alto preço do dinheiro como conseqüência lógica dessa predileção (Haddad 2003). Já os banqueiros tradicionais acham que o alto custo dos empréstimos é uma situação "necessária, mas passageira", e a normalidade — os bancos servirem fundamentalmente para auxiliar a aceleração da produção e do consumo — será restabelecida no futuro (Troster 2004).

Reparemos a astúcia da razão social: na versão brasileira do debate clássico do setor financeiro, nenhum dos contendores acha descabida a situação privilegiada da sua esfera de atuação face ao resto da sociedade. Mas o representante dos bancos estabelecidos enuncia sua transitoriedade e seu compromisso com os atores econômicos externos ao mundo das finanças. Já o segundo ator prescinde de justificativas e, indiretamente, prega a autonomia completa do setor financeiro, que não deve explicações a nenhum ator externo. ${ }^{7}$ 
Um contra o outro, o estabelecido presta contas, pelo menos na retórica, à sociedade, enquanto o recém-chegado propõe "rasgar a fantasia". $\mathrm{O}$ primeiro fala a língua da sensatez, enquanto o segundo leva às últimas conseqüências a proeminência da esfera financeira, pregando abertamente a "financeirização". Ao lembrar os compromissos dos bancos com a atividade "produtiva", o primeiro defende o setor financeiro contra eventuais ataques que o "business" possa receber de fora. E esse perigo não é pequeno, haja vista a maré moralizadora que costuma passar pelas sociedades durante as crises econômicas e nos períodos imediatamente posteriores a elas (Mackenzie 2006). No Brasil, notavelmente e como fato ainda a ser bem explicado, essas reações não foram muito fortes até agora, mas a experiência internacional mostra que o perigo não é descartável. Os representantes do segundo grupo, que defende abertamente a "financeirização", evitam ao máximo a exposição direta ao público externo (Souza 2005) e cultivam uma imagem de refinamento aristocrático segundo a qual a distância em relação ao "mundo" e certa frugalidade ajudam a compor os personagens (Dias 2000; Dávila 2004; D'Ambrosio 2004). Quando a eventualidade da exposição pública torna-se incontornável - a aparição de "DD" na CPI foi um exemplo — o "espetáculo" é cuidadosamente preparado para evitar surpresas (Peña 2005).

Mas se olharmos mais atentamente, as duas ordens de atores dividem o trabalho de legitimação: a primeira delas voltada para a sociedade e a segunda, para o público interno. A última ordem importa os instrumentos financeiros mais modernos das praças internacionais e os adapta às peculiaridades brasileiras, ao mesmo tempo em que atrai as elites das novas gerações para as finanças. Tanto os instrumentos quanto os novos entrantes, uma vez testados e legitimados, poderão mais tarde ser adotados pelos atores da primeira ordem. ${ }^{8}$ Estamos diante de uma das principais fontes de modernização do sistema financeiro como um todo e essencial para a sua preservação no longo prazo, ainda que também possa ser considerada perigosa pelos possíveis efeitos negativos na legitimação de curto prazo. Assim, ao constatarmos o processo simultâneo de cooperação e de competição entre os agentes, estamos também em face do indício da existência de um "campo" financeiro no sentido de Bourdieu (1989) e de Bourdieu e Reynaud (2003).

\section{O campo e suas criaturas}

A chave do campo permite também dar sentido à figura mítica que se constrói a partir de Daniel Dantas: ela personaliza aquela primeira fase, 
agressiva, da atividade financeira. Essa atividade quase experimental de lançamento de novos produtos, concebidos a partir da "precificação" de situações que a nossa moral (ainda?) não nos permite aceitar, normalmente é pouco saliente, pois está restrita ao mercado propriamente dito e aos poucos clientes já socializados no novo padrão. ${ }^{9}$

Entretanto, o processo de privatização dos anos FHC tornou essa "vanguarda financeira" muito mais destacada para o público externo do que apareceria em outros tempos. Nesse sentido, ficaram famosas na época as articulações "no limite da honestidade" (Duailibi 2001), executadas pela área econômica do governo federal no afã de realizar aquele objetivo ao mesmo tempo econômico e simbólico, que pretendia tornar o Estado brasileiro menor e mais ágil e também livre da "herança corporativa getulista". E elas acabaram se tornando a passarela na qual nosso personagem debutou para a opinião pública. Como o fenômeno das privatizações foi altamente simbólico e controverso, tanto em relação ao acerto da realização quanto da sua operacionalização, eis que nosso player, um dos grandes articuladores das "companhias de propósito limitado" que participaram dos leilões da época, adquire ali a imagem pública que se reforçou no período pós-FHC. ${ }^{10}$ Ao colocar a privatização como um objetivo central de governo, o período FHC precisava essencialmente de inovadores financeiros, capazes de montar as operações de compra das estatais e de estruturação das empresas recém-privatizadas. Essas atividades eram inéditas no Brasil e os inovadores financeiros, como Dantas, foram chamados a concebê-las e dirigi-las (outros bancos, que promoviam operações análogas durante o processo de privatização foram o Pactual, o Pontual, o Fibra, o Votorantin).

O personagem Dantas — bem como sua adaptação ao período posterior - é assim inexplicável sem o registro do sistema financeiro que vicejou na era FHC (Grün 2004a). O mecanismo que notabilizou a atuação de seu grupo financeiro foi o uso mais ousado da "alavancagem": montar companhias sob rígido controle, ainda que nelas o aporte de capitais advindos do grupo fosse muito pequeno em relação ao aplicado pelos seus consorciados. Aos sócios do próprio grupo, ele prometia grandes lucros em relação aos capitais empregados, embora com riscos também mais altos. Aos grupos consorciados, como os fundos de pensão, a promessa era de uma administração mais leve e lucrativa das empresas privatizadas, em comparação com o que seria esperado de uma administração tradicional. Uma vez tendo sinalizado a possibilidade da montagem de empreendimentos com o grau de alavancagem até então considerado desmesurado, ele abriu caminho para outros financistas aplicarem a mesma idéia, a qual já estava sendo aceita como razoável pelos investidores e tolerada pelas autoridades. Assim, um 
eventual impedimento à sua atuação não teria nenhum efeito mais amplo na atividade financeira nacional. Na lógica do funcionamento do campo financeiro, ele seria rapidamente substituído por outros banqueiros. E estes seriam tão ou mais agressivos que ele, já que essa condição seria suscitada pelos concorrentes e pelos clientes, além de a mídia especializada e os organismos reguladores já estarem preparados para incensar a nova magnitude desse gênero de atividade.

$\mathrm{Na}$ esfera diretamente política, o período da campanha eleitoral de 2002 teve como evento marcante o tango de aproximação entre a candidatura Lula e o mercado financeiro. Dois movimentos bem conhecidos de atração foram a "Carta aos Brasileiros" (Silva 2002) e a visita de Lula à Bovespa (Murphy 2002; Ripardo 2002). O outro ponto, de distanciamento, e que talvez não tenha ganhado o destaque que merecia, foi o episódio da tramitação do Projeto de Emenda Constitucional do sistema financeiro. Essa iniciativa foi uma das primeiras medidas do governo Lula em 2003 e o seu destino é altamente esclarecedor da relação de forças vigente no espaço que investigamos. De início, a proposta apresentava algumas medidas de contenção da atividade financeira, tais como a tentativa de pôr em prática a lei da usura, que permanece letra morta desde Getúlio Vargas (Decreto $n^{0} 22.626$, de 07/04/1933). A reação social perceptível foi a eclosão de uma fortíssima barragem de críticas ao projeto, sem que praticamente nenhuma voz relevante se levantasse a seu favor, fosse para apoiá-lo de forma direta, fosse para aperfeiçoá-lo no sentido originalmente planejado pelo governo. As pretensões reguladoras foram reduzidas ao ridículo, freando de forma durável qualquer atitude desse governo que pudesse inverter os privilégios que o setor financeiro goza no Brasil (Oliveira 2003; Leonel 2003).

Ridículo lançado, ridículo não contestado e, por fim, impugnação aceita, seguida da retificação da conduta do ridicularizado: eis aí a receita acabada da violência simbólica bem perpetrada. Ela revela a assimetria de recursos culturais reconhecidos pela sociedade e pelos indivíduos diretamente envolvidos na configuração. Ela deixa traços indeléveis na alma de quem a sofre, mas dificilmente identificamos as impressões digitais dos perpetradores. E, o que é mais importante, a luta simbólica transcorre sem que ninguém que não esteja diretamente implicado reconheça-se como parte interessada, ainda que a abrangência do problema denote o contrário. O exemplo parece indicar que a força da violência simbólica produz um halo de ridicularização que, naquele caso, afastou os eventuais apoiadores de um quadro institucional menos favorável ao setor financeiro. Dessa maneira, qualquer movimentação no sentido de criar coalizões que visem diminuir a proeminência do setor financeiro torna-se altamente improvável. Em linguagem popular, a 
sociedade brasileira, excluída da patria financiera, passa "assobiando" pela discussão do futuro do sistema financeiro, como se fosse uma briga alheia, "de brancos". E aí está a força da assimetria de recursos simbólicos que faz crer ao povo brasileiro que ele realmente merece a maior taxa de juros do mundo, ainda que não a aprecie.

\section{Finanças na fábrica: a governança corporativa}

O outro grande vetor da dominação das finanças sobre outras esferas de sociabilidade é o avanço recente da idéia de "governança corporativa" na sociedade brasileira (Grün 2003a). Através desse movimento, a definição social e jurídica de empresa está sendo mudada. O preceito maior da governança corporativa é o de que a empresa é dos acionistas e os outros atores que por ela circulam devem ter seus interesses subordinados aos primeiros. Aparentemente, a afirmação é um truísmo. Mas a idéia central, originária da teoria econômica e do mercado financeiro, é a de que a empresa moderna teria sido objeto do assalto dos dirigentes profissionais, que teriam usurpado os direitos dos acionistas, e a governança corporativa seria a forma através da qual se faria, e se asseguraria, a restauração da justiça (Fligstein e Friedland 1995). Na versão européia, os empregados das empresas e as comunidades nas quais elas estão situadas seriam coadjuvantes dos dirigentes profissionais no esbulho da propriedade dos acionistas. Dessa forma, o truísmo deflagra uma seqüência mnemônica que, de alguma maneira, restaura a idéia de empresa que existia antes do fordismo e do capitalismo dos dirigentes profissionais (Tilly 2001).

A utopia regressiva da empresa completamente controlada por seus donos não pode realizar-se na letra, e todos sabem disso. Então, surge a idéia atualizada, mais uma vez no vai-e-vem popular e erudito: já que "o que engorda o gado é o olho do dono", o melhor desenho de empresa é aquele que faz todos os seus colaboradores pensarem como se fossem seus acionistas. Daí começa a obra, ao mesmo tempo econômica e ideológica, de redesenhar as empresas de acordo com essa velha inspiração, agora renovada. O conjunto de fenômenos que uns chamam de "precarização" e outros de "flexibilização" ganha inteligibilidade sociológica quando é colocado na perspectiva do predomínio cultural do mundo das finanças (Dimaggio 2001). Os empregados são divididos em "essenciais" e "acessórios". Os primeiros serão motivados positivamente, através da metáfora da remuneração por produtividade e da propriedade de ações. Para os segundos, sobra a motivação negativa da terceirização: somente continuarão na empresa, ou alcançarão 
o status privilegiado de empregados efetivos, aqueles que derem provas cotidianas de dedicação à empresa e capacidade de trabalho.

Uma série de instrumentos de gestão vai progressivamente desenvolvendo essa individualização positiva ou negativa dos trabalhadores e também dos diversos setores das empresas, desfazendo a idéia de coletividade (Grün 2004b). A tendência começa a ficar clara com o chamado sistema de custeio ABC (Activity-Based-Costing), que propõe a mensuração completamente isolada da realização de lucro ou de despesas de cada unidade da organização. Essa finalidade seria alcançada através da abolição da diferença entre custos fixos e custos variáveis (Armstrong 2002; Colwyn Jones 2002). No esquema de custeio tradicional, os custos fixos (instalações, mão-de-obra indireta e de supervisão etc.) eram de toda a empresa, deveriam ser rateados pelos seus diversos departamentos e, assim, se constituíam na base contábil para a idéia mesma de empresa vista como um coletivo maior do que a soma simples de seus departamentos.

A finalidade organizacional da tentativa de dissociação é clara — acabar com as ambigüidades na avaliação do desempenho das empresas que impediam a completa divisão de suas atividades-meio entre as múltiplas linhas de produto ou serviços. As conseqüências sociológicas dessa individualização dos diversos setores das organizações logo começaram a se fazer sentir. O novo instrumento permite que, tanto contábil quanto cognitivamente, a empresa possa ser vista como um conjunto de unidades independentes, apenas trabalhando de forma provisória em conjunto, em suma, anunciando a idéia de organização pensada como o feixe de contratos da Agency Theory, a base da economia financeira (Fama 1980). Rapidamente a perseguição desse modelo, até então exótico, torna-se uma necessidade, provida de um roteiro claro, para alcançar a "excelência".

Numa primeira fase, a "ferramenta" foi apresentada sozinha e, mais recentemente, como um sinal da sua maturidade e naturalização dos princípios que a inspiram, ela passou a fazer parte dos grandes sistemas informáticos de gestão organizacional integrada, chamados ERPs - abreviação de Enterprise Resource Planning - e considerados de utilização praticamente obrigatória nas empresas modernas (Woods Jr. 2000; Colwyn Jones 2002). A enorme difusão desses novos instrumentos consagrou a técnica contábil e espalhou sua influência cognitiva em horizontes cada vez mais amplos, bem além do ambiente das organizações industriais para as quais eles foram concebidos.

Em seguida à contabilidade $\mathrm{ABC}$, a colonização da empresa pelo mercado financeiro recebe o auxílio de um novo e mais radical catecismo, o Economic Value Added, conhecido pela sigla EVA (Lordon 2000). Através do 
EVA, há a pretensão de efetuar uma medição direta, contínua e sistemática da lucratividade diferencial de cada unidade (i.é, além do custo de capital, das taxas médias, ou das esperadas), e mesmo de cada indivíduo engajado na empresa, o que deverá servir de base central para qualquer tomada de decisão, em especial as de investimento e de venda de ativos, além da remuneração e da dispensa de funcionários. Temos então uma seqüência interna de instauração de artefatos, ao mesmo tempo operacionais e cognitivos, que é congruente e retroalimentada pela seqüência mais geral exposta no início do texto. E disso resulta que estamos cada vez mais próximos do ideal de empresa povoada exclusivamente por exemplares da espécie do homo œconomicus, que até hoje se mantinha como uma modelação teórica e empiricamente contestada (Garcia 1986; Bourdieu 2000).

No passado, mesmo no Brasil, as grandes empresas eram vistas como comunidades regidas por princípios de reciprocidade, ainda que assimétricos e análogos a famílias (Lopes 1988). Como reação ao império das finanças, em vários países da Europa ocidental há um movimento claro no sentido de manter esta característica mesmo nas difíceis condições do momento (Aglietta e Rebérioux 2004). Mas a relação cultural de forças faz com que tais características sejam entendidas como "burocracia" e "resistência à mudança" e, assim, tornadas negativas e defensivas. Agora, o ideal de empresa, inscrito na idéia de governança corporativa e construído pela pedagogia implícita nos novos instrumentos de gestão, pede que internamente ela funcione como um microcosmo de um mercado externo "perfeito", com os mesmos constrangimentos e motivações (Fama 1980). E tudo e todos que não se aproximarem do ideal são classificados como atrasados, devendo ser substituídos.

\section{De trabalhadores a investidores}

O enquadramento cognitivo implícito na idéia de governança corporativa transforma todos, ontologicamente, em acionistas e em supervisores externos. Por que prepondera essa versão, que parece tão perniciosa para aqueles que vivem do próprio trabalho? Vemos aí a ação direta da guerra cultural mais ampla, que dissolve idéias que pareciam perenes, como a proeminência do coletivo sobre o indivíduo no trabalho. Nesse espaço cognitivo, assistimos nos últimos anos a um intenso trabalho de sedução quanto à idéia de governança corporativa, que parece estar hipnotizando os diversos e relevantes atores sociais na esfera da representação, inclusive as várias tendências da representação dos trabalhadores (Grün 2003a). Ainda que acrescentando 
algumas das suas sensibilidades e certos interesses ao conceito de governança corporativa, todos convergem no sentido de reivindicar que as empresas devam estar sempre preparadas para prestar contas aos atores externos, dos quais a figura do acionista é o protótipo, pelo menos no contexto atual (Grün 2005b).

A "prototipagem" ocorre porque as informações que os agentes externos demandam devem ser prestadas na linguagem financeira, mesmo que aparentemente seu conteúdo não se preste a esse veículo. É notável o caso das informações sociais e ambientais, que passam a ser computadas através do Índice de Sustentabilidade Empresarial (ISE). O ISE tornou-se um parâmetro relevante depois de ter sido fixado à imagem do que já ocorre no mercado financeiro norte-americano e de representar uma obra de consonância unindo os agentes empresariais e financeiros a representantes de ONGs representativas, devotadas às causas sociais e ambientais. A convergência dos diversos atores para a construção de um índice que deve medir a "sustentabilidade" é uma prova da influência do ponto de vista financeiro sobre outras considerações. Afinal, essa medição dos impactos sociais e ambientais, relevantes na atuação das empresas, servirá fundamentalmente para os investidores calcularem os riscos de suas aplicações e informarem-se sobre problemas que poderiam afetar a sua sensibilidade (Camba 2005). Os agentes externos ao mercado financeiro aceitam a "precificação" de suas causas e a expressão de suas atividades (muito provavelmente com perda de conteúdo, como em qualquer tradução) na linguagem financeira, que assim dá mais um passo no sentido de se tornar a língua franca das elites dos nossos tempos (Boyer 2004).

Nossa guerra cultural adquire assim um caráter de "guerra de colonização", na qual as finanças "catequizam" diversos grupos de atores segundo o seu evangelho. Enquanto tendência internacional, esse mesmo evangelho prega as virtudes da arbitragem como o tipo de regulação que a esfera financeira preconiza para a sociedade. Grosso modo, tal mecanismo significa a capacidade que os mercados financeiros vêm adquirindo progressivamente de "pôr na linha" indivíduos, empresas, instituições e mesmo governos nacionais, através da apreciação ou da depreciação do seu valor público (Guex 2003).

Como já é do domínio público, se o governo brasileiro pudesse cometer o desatino de baixar repentinamente a taxa básica de juros, ou de impor restrições ao trânsito de capitais externos, ou de aumentar desmesuradamente $o$ salário mínimo - ainda que estes atos façam parte das atribuições do governo de uma nação soberana - os mercados reagiriam contra tais atitudes; eles venderiam os papéis brasileiro ${ }^{11} \mathrm{em}$ seu poder e, com isso, rebaixariam o 
seu valor. As primeiras vendas desencadeariam ações análogas de outros detentores de títulos e baixas sucessivas nos valores dos ativos, e os atores econômicos nacionais — o governo em primeiro lugar — ver-se-iam em sérios apuros. Se insistisse no caminho equivocado, o governo acabaria gerando uma pressão política interna e externa de tal monta que seria obrigado a recuar, ou seria apeado do poder. Dessa maneira, a arbitragem torna-se um instrumento através do qual os mercados financeiros, na sua linguagem, tornam os governos e empresas atores econômicos racionais, impondo-lhes a lógica econômica e impedindo seus desatinos.

Notemos que, a rigor, qualquer ato advindo do fato de um comerciante descobrir que uma mercadoria custa " $x$ " numa praça e " $x+y$ " numa outra, e daí comprar na primeira para vender na segunda, é uma arbitragem. Propor que este ato singular do funcionamento dos mercados se transforme no laço fundamental da sociabilidade coloca-nos no limiar da transformação da sociedade no mercado auto-regulado - a utopia capitalista discutida e refutada por Polanyi (2001 [1944]). Para o autor, a sociedade, em nome da sua própria sobrevivência e, em especial, através de suas elites tradicionais, acaba impondo limites a essa tendência, identificada com os desejos e os interesses dos "arrivistas" sociais que eram então os industriais. Se no século XIX, o principal ponto da utopia era o mercado de trabalho totalmente desimpedido de qualquer regulamentação, hoje ele é o livre movimento de capitais. Se nossos ancestrais aprenderam que não podiam permitir o desatino do comércio de força de trabalho sem defesas que resguardassem a peculiaridade dessa "mercadoria", parece que ainda não nos demos conta de que estamos diante de uma nova investida do mesmo argumento e da mesma utopia e, possivelmente, dos mesmos perigos.

A utopia hipercapitalista da arbitragem não só identifica nosso personagem, como também é indiciária, fornecendo mais uma pista para entendermos melhor essa entidade misteriosa que é o mercado financeiro. Os players aderem a ela diferencialmente e essas diferenças movem o ator coletivo, reforçando a dinâmica geracional apontada acima. De início, não só no Brasil, mas também alhures, os atores que se identificam plenamente com a arbitragem possuem uma forte marca de idade, correspondendo à nova geração de financistas que chegou ao mercado a partir do chamado big bang, a liberalização dos mercados financeiros internacionais dos anos 1980 (Thompson 1997a, 1997b).

Através da arbitragem, a nova geração de financistas mostra-se "profissionalizada", ao mesmo tempo em que impõe à geração anterior uma imagem de "grupo de compadres" (Thompson 1997a, 1997b; Grün 2004c). No âmbito internacional, a ação da nova geração configura-se através da 
adoção de diversas inovações financeiras ${ }^{12}$ que aperfeiçoam e ampliam drasticamente o uso de derivativos e os fundos de recebíveis, que visam a dispersão de riscos e a antecipação de eventos (Mackenzie e Millo 2003). Um dos pontos centrais dessa marca geracional é o capital cultural necessário para a manipulação eficiente das novas ferramentas financeiras, as quais foram desenvolvidas recentemente por economistas com forte viés matemático (Bernstein 1992). Através delas, os valores que circulam nos mercados financeiros adquirem uma magnitude dezenas de vezes superior aos da economia "material", afetando de maneira desproporcional os seus preços. ${ }^{13}$ Dessa forma, qualquer oscilação nos mercados financeiros gera impactos muito fortes no resto da economia, conferindo uma importância inaudita aos seus participantes.

\section{O catecismo e sua variante}

Há uma antropologia filosófica implícita naquela face nua da atividade financeira de vanguarda. A idéia de indivíduo racional subsocializado, que aparentemente está restrita apenas à modelagem das simulações de comportamento, ganha aqui um sentido ontológico. Não é mais apenas aquele artefato a ser acolhido ou repelido, mas um exemplo de conjunto de virtudes a ser alcançado. Nessa chave, o imperialismo dos economistas racionais mainstreamers - essa tendência do pensamento neoclássico de invadir zonas de reflexão (aparentemente?) distantes da economia - ganha outra dimensão, bem mais ampla do que aquela do debate acadêmico. Os diversos ensaios dos economistas, na aparente tentativa de descrever e analisar assuntos como o casamento, a educação, a criminalidade e a ansiedade, embutem essa colonização do imaginário (Langoni 1973; Becker 1981; Coleman 1985; Giannetti 2005). No debate intelectual, a refutação científica daquelas digressões não as derruba. Afinal, elas não são constatações empíricas. Numa lógica que é mais facilmente identificada quando presente em livros de auto-ajuda ou em sermões religiosos, elas constituem proposições sobre como devemos nos portar para sermos mais felizes, bem-sucedidos, puros ou zens. Portanto, esses economistas não são intelectuais no sentido pós-affaire Dreyfus (Charle 1990), mas naquele tradicional, dos membros do alto clero medieval descritos por Duby (1978). Isto quer dizer que o produto da sua labuta intelectual não é diretamente analítico, mas propositivo e performático. Nesse registro, a eficiência social dos economistas-intelectuais dá-se pela disseminação polissêmica dos conceitos econômicos do mainstream, que produz as metáforas através das quais a realidade passa a ser pensada. 
Forma-se, assim, o conjunto de restrições que acaba se impondo como os limites do "bom-senso" não só econômico, mas também de outras esferas da sociabilidade contemporânea.

Um dos ardis da dominação financeira é justamente aquele em que a crítica acerba dos métodos e dos resultados do veio analítico, que corresponde à supremacia da razão financeira, dá pouca importância aos efeitos metafóricos dos empreendimentos culturais que as finanças patrocinam. Assim como acontece com as questões de gênero, a crítica à dominação financeira é pouco sensível ao seu ponto fulcral, que é a dificuldade do dominado pensar a realidade através de categorias de pensamento que não sejam as produzidas pelo e para o dominante (Bourdieu 2002). Dessa maneira, desviando a crítica direta, o modo de dominação financeiro instaura-se em zeitgeist, instituindo ao mesmo tempo a legitimação dos atores daquele espaço e indicando o caminho que todos devem seguir para adentrar nesse novo nirvana da racionalidade, como se isso fosse realmente possível.

Por fim, a dinâmica da configuração intelectual ficaria capenga se não considerássemos a chamada "terceira via". Em princípio, ela é uma interpretação da realidade contemporânea distinta, logo, concorrente à da dominação financeira. Ela caracteriza a época em que vivemos como a da flexibilidade. Esta qualidade é louvada como a oposição às formas burocráticas das fases anteriores do desenvolvimento da sociedade, que cerceavam não só o seu crescimento econômico e tecnológico, como também a evolução dos indivíduos. Nessa crítica, de tonalidade weberiana, a burocracia é a "gaiola de ferro" que produz conformismo e mediocridade e impede a prevalência da razão substantiva (Powell 2001). Os heróis do tempo são aqueles capazes de agregar continuamente outros indivíduos e dispositivos em novos projetos, econômicos ou de outra natureza, impulsionando todos a uma maior circulação e a novas experiências (Boltanski e Chiapello 1999).

Diferente das idéias individualistas e neodarwinistas propagadas pelas finanças, nessa formulação das características do tempo presente, os agentes ganham quando apostam na cooperação e perdem quando imaginam os seus interesses como contrapostos aos daqueles com quem entram em contato comercial ou de outra natureza. Para Boltanski e Chiapello (1999), essa formulação é ainda um resultado teórico, depreendido da análise dos potenciais de virtuosidade existentes nos manuais do management: trata-se assim de cobrar lógica das justificativas presentes nas prescrições sobre como devem ser as empresas e as demais organizações modernas. Se as organizações estão realmente no caminho que afirmam estar e, principalmente, se a sociedade conseguir cobrar isso delas, então teremos o mundo conexionista. Trata-se assim de uma pedagogia explícita sobre o aprendizado das poten- 
cialidades da nova era. Nesse quadro, a "financeirização" não passaria de um desvio temporário, que seria corrigido quando a sociedade percebesse o potencial que está sendo desperdiçado pelo excesso de competição e por outras manifestações de individualismo.

Para Dimaggio (2001) e Dimaggio et alii (2001), essa construção é ao mesmo tempo uma metáfora viva, criada no halo da repercussão social do sucesso da internet, e também uma "sociodicéia", extraída dos exemplos de vidas bem-sucedidas de consultores empresariais que fazem das peculiaridades de sua inserção econômica uma virtude cardinal de nosso tempo. Dessa maneira, ela corrobora e introduz nuances na visão "bourdieusiana" que chama a atenção para as dificuldades dos indivíduos não socializados em espaços de elite no momento de encararem os "desafios" profissionais e interpessoais propostos pela idéia de rede (Bourdieu e Accardo 1993; Balasz 1996; Grün 2003b).

A versão erudita e "positiva" da idéia de rede que obteve maior sucesso editorial (alcançando a $7^{\text {a }}$. edição brasileira em 2003) foi uma extensa e informada obra sociológica de Castells $(1996,1997)$. Não por acaso, um volume de sua versão brasileira foi prefaciada por Fernando Henrique Cardoso (Castells 2005 [1999]), enquanto o outro o foi por Ruth Cardoso (Castells 2002 [1999]). Por ter criado um nicho ecológico extremamente favorável às novas finanças, eis que o Presidente FHC, secundado por Ruth Cardoso, volta à atividade intelectual stricto sensu para caucionar a visão de presente e futuro que esmaece a proeminência da dominação financeira.

A ação inusitada do então Presidente da República e sua esposa é altamente reveladora do que está em jogo. O enquadramento "sociedade em rede" é otimista e torna positivas as características ainda controversas da atualidade. Para os que cultivam a imagem de "moderno", é gratificante associar-se à idéia de sociedade em rede, que ganhou um caráter inequívoco de tendência intelectual bem-sucedida. Além de constrangimentos identitários ou políticos, a idéia também fornece uma justificativa suplementar, e robusta, para a obra de desmantelamento das "pesadas" estruturas econômicas e trabalhistas que o Brasil herdou do período getulista. Para muitos intelectuais e jornalistas, esse objetivo parece ter sido a versão contemporânea da busca do Santo Graal, que resolveria os problemas brasileiros (Grün 2005b).

$\mathrm{Na}$ disputa ideológica que subsume a prática política, esse objetivo é compreendido quando imaginamos o espaço em que trafegava o ex-presidente e seu séqüito: dado o seu passado e a sua sensibilidade, nenhum deles pode aderir explicitamente à versão de modernidade neodarwinista proposta pelas finanças. Por outro lado, os petistas, seus inimigos políticos e ideológicos mais evidentes, tornaram-se patrões incontestes da defesa do 
"patrimônio nacional", representado pelo universo das empresas estatais e pelo modelo de desenvolvimento econômico e social do qual elas eram o centro. Defender esse projeto "nacional-desenvolvimentista" parecia a principal tarefa dos oponentes de FHC. Nesse quadro de constrangimentos, a adesão à idéia de "sociedade em rede" era um atrativo muito forte, pois fornecia um excelente espaço de referências no qual o Presidente e seu grupo se localizariam. Além disso, ela é um produto incontestavelmente sociológico, que fornece referências e enquadramentos intelectualmente legítimos para os que não se conformam à visão de mundo implícita na pregação financeira (e não é por acaso que esta última não aparece explicitamente na arena pública).

Sugiro assim que estamos diante de uma nuance do conflito cultural mais geral. O grupo que esteve no poder precisava de uma versão legítima para interpretar os tempos que ele estava ajudando a desenvolver, e que fosse palatável para ele mesmo e para grande parte de seus apoiadores, em geral situados nos pólos dominantes de diversos campos disciplinares e profissionais. Mesmo não se reduzindo a isto, a idéia de "sociedade em rede" fornece elementos para a construção de tais justificativas para o sucesso profissional — as teodicéias modernas que Bourdieu chama de sociodicéias (Bourdieu 1989). A idéia de capital social, que originalmente indicava uma assimetria social que explica vantagens de indivíduos e grupos, vira aqui uma qualidade intrinsecamente positiva que culpabiliza aqueles que não a possuem. Ainda que em algumas versões a pregação funcione como na auto-ajuda, tentando auxiliar os indivíduos a superar os constrangimentos das estruturas sociais, no mais das vezes, quando anunciada a necessidade de superar as determinações, a sua não-realização passa a ser debitada ao looser, que assim tem de se conformar com a sua sorte (Grün 2003b). Um efeito irrefutável que a idéia de sociedade em rede produz é, como mostram os estudos de "agenda-setting", o do enquadramento e saturação da agenda, ocupando o espaço das possíveis discussões sobre os rumos da sociedade (Aday 2003). Mesmo não sendo intencional, esse efeito esconde as evidências que indicam a sistematicidade da lógica da "financeirização".

No campo do poder, a nuance introduzida pela idéia de sociedade em rede confere um lugar distintivo para uma elite intelectual no senso estrito. Além dos seus atributos funcionais básicos, ela se distingue da nova elite econômica pela sua adesão às regras do jogo intelectual explícito. Essa diferença de sensibilidades reflete muito provavelmente uma diferença de habitus, que poderia ser explorada como possível fonte dinamizadora do campo do poder no Brasil, e também da dinâmica interna do seu espaço intelectual. No que diz respeito ao modo de dominação financeiro, essa 
adesão ao campo do poder mostra, ao lado da concorrência cultural direta com os "novos intelectuais" economistas, uma relação mais complexa de cooperação no que diz respeito à manutenção da estabilidade simbólica para essa configuração que acabo de descrever, já que o efeito ideológico da sua postulação parece evidente. Entre outros motivos, porque o enquadramento dos tempos atuais como os da "financeirização" ou do "modo de dominação financeiro" soam como jeremiadas destituídas de interesse midiático e excessivamente pessimistas para serem empalmadas sem a caução de algum setor das elites, agora mesmerizadas pelo encantamento das finanças.

\section{Das dificuldades e das armadilhas estruturais da oposição ao predomínio das finanças}

Finalmente, é também um dado de realidade que a dinâmica do conflito cultural seqüenciado acima como $[\mathrm{T}(1) \rightarrow \mathrm{T}(2) \rightarrow \mathrm{T}(3)]$ produza um $\mathrm{T}(4)$, que provavelmente seria uma volta nuançada a $\mathrm{T}(1)$. A dinâmica cultural impõe que as reações explícitas à dominação financeira tentem criar um símbolo antifinanceiro. Tanto a lógica histórica quanto a mnemônica tendem a convergir para que esse símbolo se baseie no arquétipo do plutocrata, que as sociedades ocidentais herdaram do anti-semitismo e dos escândalos financeiros do século XIX e da crise de 1929. Assim, a história recente nos ensina que a receptividade maior para aquele símbolo ocorre como reação a crises financeiras de grande amplitude no que diz respeito às repercussões na vida econômica mais geral (Birnbaum 1979; Mcgerr 1986; Sternhell 1997; Mackenzie 2003; Mackenzie e Millo 2003).

Surgiram na cena brasileira (mas também sumiram) Naji Nahas, Armínio Fraga, dentre aqueles do final do século XX. Mais recentemente, Daniel Dantas recebeu essa função. Um outro ardil da dominação financeira é que essa linha socio-lógica acaba normalmente reforçando também a sua importância. O combate ao "plutocrata" tende a se tornar um artefato da luta política, o qual é melhor manejado pelas tendências mais extremas daquele cenário. Não é por acaso que os fascistas italianos e os nazistas alemães tenham sido seus manipuladores mais eficientes e, internamente a esses grupos, os militantes oriundos da extrema esquerda foram aqueles que melhor e mais consistentemente utilizaram o espectro (Sternhell 1997). Mas a receptividade para esse gênero de pregação, lançada por grupos marginalizados no jogo político habitual, só ocorre em momentos pouco freqüentes de tensão extrema. Normalmente, como mais uma manifestação da violência simbólica produzida pelos grupos e pelas instituições cultural- 
mente dominantes, ela passa por idiossincrática e entra para a galeria das curiosidades da época, dissipando a energia social que poderia se opor à predominância financeira, além de entreabrir a sempre perigosa caixa de Pandora de onde sai o extremismo de direita.

Recebido em 31 de outubro de 2005

Aprovado em 24 de março de 2007

Roberto Grün é professor do Departamento de Engenharia da Produção da Universidade Federal de São Carlos. E-mail: <rgrun@uol.com.br>

\section{Notas}

${ }^{1}$ A expressão "Daniel Dantas" obteve o seguinte número de menções no jornal Folha de São Paulo nos últimos anos: 2000 - 104; 2001 - 61; 2002 - 71; 2003 - 24; 2004 $134 ; 2005$ - 344; 2006 (até 09/07) - 173. Uma síntese da figura pública do personagem (Globo, 22/09/2005), em "A história do baiano Daniel Dantas no Rio", começou em 1979. Na Fundação Getúlio Vargas, era o aluno preferido do ex-ministro Mario Henrique Simonsen, que o indicou para o Bradesco, onde chegou a vice-presidente. Dantas saiu do Bradesco junto com Antonio Carlos de Almeida Braga e foi administrar a fortuna dele no Banco Icatu, criado em 1986. O Icatu prosperou e Dantas acabou deixando o negócio. Foi então que criou o Opportunity, em meados da década de 90. Também foi Simonsen quem apresentou Dantas a Fernando Collor de Mello, e o banqueiro chegou a ser sondado para ministro. Com esse currículo de gênio das finanças, ele passou a ser conhecido, no entanto, pelas polêmicas. Meses depois do leilão do Sistema Telebrás, em 1998, vieram à tona escutas telefônicas que flagraram negociações feitas antes da privatização: o então ministro das Comunicações, Luiz Carlos Mendonça de Barros, articulava, entre outros assuntos, benefícios ao Opportunity para participar da compra das empresas, num episódio que ficou conhecido como o grampo do BNDES. Para as privatizações da década passada (de 1990-RG), o Opportunity montou fundos de investimentos com dinheiro de fundos de pensão e do Citigroup. Pela estrutura desses fundos de private equity, o investidor colocaria o dinheiro e o gestor seria o Opportunity, com pouca participação acionária. Em 2000, as relações começaram a azedar. Os fundos de pensão entraram na Justiça alegando poder excessivo do gestor, que retrucava que os investidores não deveriam interferir na condução das empresas. Em 2003, os fundos de pensão conseguiram destituir o Opportunity do private equity CVC. Este ano, o Citi, que até então apoiara Dantas em todas as brigas, fez o mesmo. Agora Citi e fundos de pensão estão finalizando a tomada de controle das empresas geridas pelo Opportunity, 
como o Metrô do Rio, a Brasil Telecom (BrT), a Telemig Celular e a Amazônia Celular. O Opportunity brigou também com outro sócio, a Telecom Italia, por causa do preço que a BrT pagou pela CRT. Este ano, no entanto, os dois entraram em um acordo para o Opportunity vender sua parte na BrT aos italianos. Em 2004, o Opportunity saltou das brigas societárias para um grande escândalo político: descobriu-se que a empresa de espionagem Kroll fora contratada pela BrT para investigar a Telecom Italia. Até mesmo o e-mail do ex-ministro Luiz Gushiken foi rastreado.

${ }^{2}$ Originalmente em Kotcho (1976). Encontra-se uma transcrição acessível, com dados biográficos e bibliográficos do autor e das circunstâncias da reportagem, em Kotcho (2005).

${ }^{3}$ A frase ficou famosa e, paradoxalmente, a sua expressão original difícil de ser recuperada. Fernando Collor de Mello relata o contexto em que a teria dito pela primeira vez (numa reunião com dirigentes da Volkswagen alemã antes de sua posse) no seguinte caminho: http://gazetaweb.globo.com/gazeta/Frame.php?f=Materia.php\&c $=3187 \& \mathrm{e}=77$

${ }^{4}$ No dicionário autorizado de Ferreira (1975), proverbialmente, ela ainda não aparecia, estando registrado apenas: "cargo ou ofício de mordomo". Já em Houaiss et alii (2001), a expressão tem o seu registro presente: "substantivo feminino. 1. função, ofício de mordomo; mordomado; 2. Regionalismo: Brasil. Conjunto das vantagens (seguros, alimentação, condução etc.) oferecidas pelo empregador aos empregados ou a uma parte deles, em determinados estabelecimentos particulares, ou pela União, Estado ou Município a determinados funcionários públicos, além do salário estipulado, sem onerar-lhes o imposto de renda (mais us. no pl.) Ex.: um parlamentar com muitas m; 3. Rubrica: direito público. Uso: pejorativo. Abuso de poder na utilização do patrimônio público para atender interesses particulares; 4. Regionalismo: Brasil. Qualquer regalia, conforto que se pode desfrutar, sem que se tenha de despender qualquer esforço. Ex.: naquela casa, vivia cheio de m.

${ }^{5}$ Registremos que a dinâmica desse jogo mostra alguns episódios de sucesso na defesa dos pontos de vista dos planejadores/engenheiros. Talvez o mais notável dos últimos anos tenha sido a seqüência de episódios envolvendo a tentativa de transformar a Petrobras em Petrobrax, seguido do naufrágio da plataforma de extração de petróleo P4 e da evicção do então presidente da empresa, Henri Reichstul. Mas, como um bom exemplo da cegueira institucional formulada por Douglas (1986), a lógica da trama cultural mais ampla joga o próprio exemplo no oblívio. Da mesma maneira, podemos seguir a guerra de interpretações em torno da crise energética do segundo período de Cardoso (Grün 2005a).

${ }^{6}$ Douglas e Ney (1998) mostram o caráter metafórico das hipóteses da teoria econômica "mainstream" e suas implicações na aceitação de seus argumentos. Lakoff (1996, 2004) mostra como esse conteúdo metafórico está enraizado na moralidade privada das sociedades ocidentais e como daí ele se estende para a esfera pública.

${ }^{7}$ E não é difícil classificar o seu ponto de vista na linhagem da Economia Política clássica, que justificava eficientemente situações, como a da fome, na Índia colonial (Thompson 1998). 
${ }^{8}$ Nem todos, evidentemente. E esse é o risco dos inovadores, assim como o seu fundo de comércio, já que eles são "bancados" por investidores ávidos por taxas de retorno mais elevadas do que a média de mercado e, por isso, estão mais propensos a assumir riscos. Mas a interpenetração das duas ordens de atores é cada vez mais notável, por exemplo, quando os bancos tradicionais "terceirizam" carteiras de investimentos para serem administradas por novos entrantes (e inovadores) do campo (D'Ambrosio 2003).

${ }^{9} \mathrm{O}$ caso mais conhecido, e estudado, é o do lançamento do seguro de vida. Durante muito tempo, essa mercadoria foi considerada imoral e manteve-se interditada, pois dizia-se que induziria os beneficiários do seguro a desejarem a morte do segurado. Até que finalmente a sociedade se acostumou com a idéia e o consumo generalizou-se (Zelizer 1979).

${ }^{10}$ Durante o período FHC, as articulações do banco Opportunity de Daniel Dantas, bem como aquelas ensaiadas por outros bancos de investimentos foram amplamente apoiadas por setores do governo federal, às expensas dos fundos de pensão das empresas estatais, que tiveram de se conformar à posição de provedores passivos de capitais para nossos "players". No início do período Lula, os fundos tentaram desfazer os entendimentos que os prejudicavam, e o contencioso tornou-se público através dos episódios de espionagem executados pela "Kroll" (Michael 2004; Souza e Alencar 2005; Leite 2004). Dessa maneira, Dantas voltou às manchetes dos periódicos, nas quais continuou no final do primeiro termo do governo Lula.

${ }^{11}$ Os títulos podem ser certificados da dívida nacional, reais propriamente ditos, títulos de empresas e bancos brasileiros e outros papéis emitidos por atores brasileiros ou "denominados" em reais.

${ }^{12}$ O termo "inovação" é meio capcioso. A quase totalidade das operações financeiras que são praticadas agora já é conhecida desde muito. Por exemplo, Bernstein (1992) fala de contratos para o uso futuro de prensas de azeitona na Grécia Clássica e Penso De La Vega (1977) faz uma descrição do mercado de futuros e derivativos, ele, um contemporâneo de Spinoza. A novidade, muito provavelmente, está no uso muito mais intenso da panóplia financeira, tornado possível pelo avanço da tecnologia de cálculo e de comunicações. No momento atual, pela informática e pela Internet.

${ }^{13}$ Dessa maneira, explica-se o aumento "exagerado" do preço do barril de petróleo, em função de esse produto ser um dos que mais geram derivativos (Brandão 2001). Uma vez que o mercado de derivativos especula - sobretudo sobre os preços da mercadoria no futuro, ao invés dos custos de produção no presente - qualquer avaliação pessimista sobre o tamanho das reservas mundiais, sobre a sua localização em zonas de possível tensão política, ou ainda da expectativa de invernos rigorosos no hemisfério norte ou de verões muito quentes na Califórnia, geram fortes impactos no preço presente da gasolina, do diesel e mesmo do álcool combustível. 


\section{Referências bibliográficas}

ADAY, Kimberly Gross Sean Aday. 2003. "The scary world in your living room and neighborhood: using local broadcast news, neighborhood crime rates, and personal experience to test agenda setting and cultivation". Journal of Communication, 53(3):411-426.

AGLIETTA, Michel. e REBÉRIOUX, Antoine. 2004. Dérives du capitalisme financier. Paris: Albin Michel.

ARMSTRONG, Peter. 2002. "The costs of acitivity-based management". Accounting, Organizations and Society, 27(12):99-120.

BALASZ, Gabrielle e FAGUER, JeanPaul. 1996. "Une nouvelle forme de management, I'évaluation". Actes de la Recherche en Sciences Sociales, 114:68-78.

BAUTZER, Tatiana. "Brasil quer ampliar poder de voto de emergentes nas decisões do FMI: Palocci sugere novo cálculo de cotas, com a adoção de maioria de 70\%". Valor Econômico, São Paulo, 18/04/2005.

BECKER, Gary S. 1981. A treatise on the family. Cambridge, Mass.: Harvard University Press.

BERNSTEIN, Peter. 1992. Capital ideas: the improbable origins of modern Wall Street. New York/ Toronto: Free Press/ Maxwell Macmillan International.

BIRNBAUM, Pierre. 1979. Le peuple et les gros: histoire d'un mythe. Paris: B. Grasset.

BOLTANSKI, Luc \& CHIAPELLO, Eve. 1999. Le nouvel esprit du capitalisme. Paris: Gallimard (NRF essais). .et alii. 1984. "La dénonciation". Actes de la Recherche en Sciences Sociales, 51:3-40.

BOURDIEU, Jerôme. J. H. \& REYNAUD, E. B. 2003. "Les structures sociales de la finance". Actes de la Recherche en Sciences Sociales, 146-147:3-7.

BOURDIEU, Pierre. 1989. La noblesse d'état: grandes écoles et esprit de corps. Paris: Minuit.

. 1992. Les règles de l'art: genèse et structure du champ littéraire. Paris: Editions du Seuil (Libre examen. Politique). . 1997. Méditations pascaliennes. Paris: Seuil.

2000. Les structures sociales de l'économie. Paris: Seuil (Collection Liber).

2002. La domination masculine: suivi de quelques questions sur le mouvement gay et lesbien. Paris: Seuil. . \& ACCARDO, A. 1993. La misère $d u$ monde. Paris: Editions du Seuil (Libre examen).

BOYER, Robert. 2004. Une théorie du capitalisme est-elle possible? Paris: Odile Jacob.

BRANDÃO, F. “Entendendo a formação dos preços de petróleo no mercado internacional". Infopetro, 07/2001.

CAMBA, Daniela. "O que é ser socialmente responsável?: entidades e empresas travam batalha para definir critérios que deixariam ações de fora do Índice de Sustentabilidade em preparação pela bolsa". Valor Econômico, São Paulo, 30/03/2005.

CARVALHO, M. C. "PIS e Cofins têm impacto limitado". Valor Econômico, São Paulo, 20/08/2004.

CASTELLS, Manuel 1996. The rise of the network society. Cambridge, MA: Blackwell Publishers. 1997. The power of identity. Cambridge, MA: Blackwell. . 2002 [1999]. O poder da identidade (Prefácio de Ruth Correia Leite Cardoso). São Paulo: Paz e Terra. 3.ed. 
2005 [1999]. A sociedade em rede: a era da informação: economia, sociedade e cultura (Prefácio de Fernando Henrique Cardoso). São Paulo: Paz e Terra. 8a.ed.

Charle, Christophe. 1990. Naissance des "intellectuels", 1880-1900. Paris: Editions de Minuit (Le sens commun).

COLEMAN, J. W. 1985. The criminal elite: the sociology of white collar crime. New York: St. Martin's Press.

COLWYN JONES, T. D. 2002. "The ABC bandwagon and the juggernaut of modernity". Accounting, Organizations and Society, 27:121-163.

CRUZ, N. H. D. 2006. "Levantamento com 107 países mostra que, além de ter maior taxa básica, Brasil lidera também na taxa ao consumidor: Bancos do país cobram maior juro do planeta". Folha de São Paulo, São Paulo, 16/02/2006.

D'AMBROSIO, C. V. E. D. 2003. "Fundos multimercados voltados para o público de alta renda se multiplicam em velocidade espantosa: quase um novo produto é lançado por dia: Os novos VIPS". Valor Econômico, São Paulo, 16/10/2003.

2004. "Independentes com patrimônio de R\$ 1 bi: clube do bilhão". Valor Econômico, São Paulo, 19/01/2004.

DÁVILA, S. 2004. "República do Leblon cresce e aparece". Folha de São Paulo, 18/01/2004.

DIAS, L. 2000. "Realeza no green: o que acontece quando os nobres da economia e finanças se encontram entre uma tacada e outra". Isto é Dinheiro, $172,08 / 12 / 2000$.

DIMAGGIO, Paul. 2001. The twentyfirst-century firm: changing economic organization in international perspective. Princeton, N. J.: Princeton University Press.
.; HARGITTAI, Ezter et alii. 2001.

"Social implications of the internet". Annual Review of Sociology, 27(1):307-336.

DOUGLAS, Mary. 1986. How institutions think. Syracuse, N.Y.: Syracuse University Press.

. 1996. Thought styles: critical essays on good taste. London/ Thousand Oaks, Calif.: Sage.

. ; HULL, David. L. et alii. 1992. How classification works: Nelson Goodman among the social sciences. Edinburgh: Edinburgh University Press.

\& NEY, Steven. 1998. Missing persons: a critique of the social sciences. Berkeley/ New York: University of California Press; Russell Sage Foundation.

DUAILIBI, J. 2001. "Ex-ministro Mendonça de Barros depõe na Justiça e diz que escuta serviu a vencedor no leilão da Telebrás: Mendonça liga ex-diretor do BB a grampo". Folha de São Paulo, 26/04/2001, A13p.

DUARTE, F. 2006. "Exploring the interpersonal transaction of the brazilian jeitinho in bureaucratic contexts". Organization, 13:509-527.

DUBY, Georges. 1978. Les trois ordres ou l'imaginaire du féodalisme. Paris: Gallimard.

DURAND, José Carlos; RATTNER, Henrique et alii. 1979. Pequena e média empresa no Brasil, 1963/1976. São Paulo: Edições Símbolo.

EVANS, Peter. 1979. "A tríplice aliança: as multinacionais, as estatais e o capital nacional no desenvolvimento dependente brasileiro". In: Dependent development: the alliance of multinational, state and local capital in Brazil. Princeton: Princeton University Press.

FAMA, Eugene. F. 1980. "Agency proble$\mathrm{ms}$ and the theory of firm". Journal of Political Economy, 88(2):288-307. 
FAUCONNIER, Gilles. 1999. Mappings in thought and language. Cambridge/ New York: Cambridge University Press.

FERREIRA, Aurélio. B. Hollanda. 1975. Novo dicionário da língua portuguesa. Rio de Janeiro: Editora Nova Fronteira.

FLIGSTEIN, Neil \& FRIEDLAND, Robert. 1995. "Theoretical and comparative perspectives on corporate governance". Annual Review of Sociology, 21:21-43.

GALBRAITH, John Kenneth. 1998. The affluent society. Boston: Houghton Mifflin NetLibrary Inc.

GARCIA, Marie-France. 1986. "La construction sociale d'un marché parfait: le marché au cadran de Fontaines-en-Sologne". Actes de la Recherche en Sciences Sociales, 65:2-13.

GIANNETTI, Eduardo. 2005. O valor do amanhã: ensaio sobre a natureza dos juros. São Paulo: Companhia das Letras.

O Globo. "Um empresário polêmico". Rio de Janeiro, 22/09/2005.

GRÜN, Roberto. 1999. "Modelos de empresa, modelos de mundo: sobre algumas características culturais da nova ordem econômica e da resistência a ela". Revista Brasileira de Ciências Sociais, 14:121-140.

. 2003a. "Atores e ações na construção da governança corporativa brasileira". Revista Brasileira de Ciências Sociais, 18(52):121-143.

.2003b. "A promessa da 'inserção profissional instigante' da sociedade em rede: a imposição de sentido e a sua sociologia". Dados - Revista de Ciências Sociais, 46(1):5-37.

. 2004a. "A evolução recente do espaço financeiro no Brasil e alguns reflexos na cena política". Dados - Revista de Ciências Sociais, 47:5-47.
. 2004b. "O 'MBA' como um brevê de internacionalização e de contemporaneidade profissional entre engenheiros". In: A. M. de Almeida et alii (orgs.), Circulação internacional e formação intelectual das elites brasileiras. Campinas: EdUnicamp. pp. 282-298.

2004c. "A sociologia das finanças e a nova geografia do poder no Brasil". Tempo Social, 16(2):151-176. .2005a. "Apagão cognitivo: para uma sociologia da crise energética". Dados - Revista de Ciências Sociais, 48(4):891-928.

. 2005b. "Convergência das elites e inovações financeiras: a governança corporativa no Brasil". Revista Brasileira de Ciências Sociais, 20(58):67-90.

GUEX, Sebastien. 2003. "La politique des caisses vides: État, finances publiques et mondialisation". Actes de la Recherche en Sciences Sociales, 146-7:51-61.

HADDAD, Claudio. 2003. "Vendendo ilusão". Valor Econômico, São Paulo, 05/12/2003.

HIRSCH, Paul M. D. \& MICHAELA, S. 2006. "Organizational restructuring and its consequences: rhetorical and structural". Annual Review of Sociology, 32.

HOUAISS, Antonio et alii. 2001. Dicionário Houaiss da língua portuguesa. Rio de Janeiro: Objetiva.

JOSEPH, W. O. A. J. 2005. "Cultural adaptation and institutional change: the evolution of vocabularies of corporate governance, 1972-2003". Poetics, 33(3-4):163-178.

KOTCHO, Ricardo. 1976. "Assim vivem os nossos superfuncionários". Estado de São Paulo, São Paulo, 01/08/1976.

2005. "Mordomias". In: F. Molica (org.). 10 reportagens que abalaram a ditadura. Rio de Janeiro/ São Paulo: Record. pp. 141-174. 
LAKOFF, G. 1996. Moral politics: what conservatives know that liberals don't. Chicago: The University of Chicago Press.

2004. Don't think of an elephant!: know your values and frame the debate: the essential guide for progressives. White River Junction: Chelsea Green Pub.

LANGONI, Carlos Geraldo. 1973. Distribuição da renda e desenvolvimento econômico do Brasil. Rio de Janeiro: Editora Expressão e Cultura.

LEITE, P. D. 2004. "'Estou preocupado', ironiza Dirceu". Folha de São Paulo, São Paulo, 30/10/2004.

LEONEL, Rita Tavares e Josué Leonel. 2003. "Fechado acordo para votar mudança no sistema financeiro, diz petista". O Estado de São Paulo, São Paulo, 26/03/2003.

LOPES, José Sergio Leite. 1988. A tecelagem dos conflitos de classe na "cidade das chaminés". São Paulo/ Brasília: Editora Marco Zero/ EdUnB.

LORDON, Federic. 2000. "La 'création de valeur' comme rhétorique et comme pratique. Généalogie et sociologie de la 'valeur actionnariale'". L'Année de la Régulation: Économie, Institutions, Pouvoirs, 4:117-170.

MACKENZIE, Donald. 2003. "Longterm capital management and the sociology of arbitrage". Economy and Society, 32(3):349-380.

2006. An engine, not a camera: how financial models shape markets. Cambridge: MIT Press. \& MILLO, Y. 2003. "Constructing a market, performing theory: the historical sociology of a financial derivatives exchange". American Journal of Sociology, 109(1):107-45.

MCGERR, Michael. E. 1986. The decline of popular politics: the American North, 1865-1928. New York: Oxford University Press.
MICHAEL, Andréa. 2004. "Kroll tinha fortes ligações com a área policial, diz PF". Folha de São Paulo, 04/08/2004, A11p.

MURPHY, P. 2002. "Esquerda e Bovespa fazem aliança estratégica: para presidente da Bolsa, 'muro de Berlim caiu' com a inédita visita de Lula ao pregão". O Estado de São Paulo, 01/09/2002.

NETTO, Antonio Delfim. 2004. "Exportação = salvação". Folha de São Paulo, 25/08/2004.

OLIVEIRA, R. 2003. "Governo já tem proposta para mudar o 192". Valor Econômico, São Paulo, 19/02/2003.

PAVINI, Angelo. 2004. "Bovespa quer atrair mais empresas e aplicadores em ações: estratégia inclui mercado de acesso, pedido de linha para o BNDES e atuação nas embaixadas". Valor Econômico, São Paulo, 27/07/2004.

PEÑA, Bernardo de la e VASCONCELOS, Adriana. 2005. "Deputados e senadores trocam tapas e empurrões". O Globo, Rio de Janeiro, 22/09/2005.

PENSO DE LA VEGA, José. 1977. Confusion de confusiones: dialogos curiosos entre un philosopho agudo, un mercader discreto, y un accionista erudito. Valencia: Saetabis.

PEREIRA, Luis Carlos Bresser. 1974. Empresários e administradores no Brasil. São Paulo: Editora Brasiliense.

POLANYI, Karl. 2001 [1944]. The great transformation: the political and economic origins of our time. Boston: Beacon Press.

POWELL, Walter W. 2001. "The capitalist firm in the twenty-first-century: emerging patterns in Western enterprise". In: P. Dimaggio (org.), The twenty-first-century firm: changing economic organization in international perspective. Princeton: Princeton University Press. pp. 33-67. 
RIPARDO, Sérgio. 2002. "'Projeto Bovespa-Lula' reedita propostas do plano diretor de abril". Folha Online, 01/10/2002 - 19h40.

ROMERO, Cristiano. 2004. "Receita estuda cortar impostos e nova lei pode forçar concorrência: Governo e Congresso lançam ofensiva contra os juros altos". Valor Econômico, São Paulo, 20/08/2004.

SALOMÃO, Marta. 2003. "Desemprego alto segura inflação, diz Ipea". Folha de São Paulo, 03/03/2003.

SCHORSKE, Carl. 1979. "Conflit de générations et changement culturel. Réflexions sur le cas de Vienne". Actes de la Recherche en Sciences Sociales, 26-27:109-116.

SILVA, Luiz Ignácio Lula da. 2002. "Carta ao povo brasileiro" (http://www. pt.org.br/site/assets/carta_ao_povo_ brasileiro.pdf): Partido dos Trabalhadores, 22/06/2002.

SOUZA, J. D. 2005. "Só um incêndio geral e irrestrito salva o Brasil". Folha de Sáo Paulo, 11/09/2005.

SOUZA, L. \& ALENCAR, Kennedy. 2005. "Deputado do PFL 'clona' ação a favor do Opportunity". Folha de São Paulo, São Paulo, 23/08/2005.

STERNHELL, Zeev. 1997. La droite révolutionnaire, 1885-1914: les origines françaises du fascisme. Paris: Gallimard.
THOMPSON, Edward P. 1998. Costumes em comum: estudos sobre a cultura popular tradicional. São Paulo: Cia das Letras. . 1997a. "The pyrrhic victory of gentlemanly capitalism: the financial elite of the City of London, 1945-90". Journal of the Contemporary History, 32(3): 283-304. . 1997b. "The pyrrhic victory of gentlemanly capitalism: the financial elite of the City of London, 1945-90, part 2". Journal of Contemporary History, 32(4):427-440.

TILLY, Charles. 2001. "Welcome to the seventeenth century". In: P. Dimaggio (org.), The twenty-first-century firm: changing economic organization in international perspective. Princeton: Princeton University Press. pp. 200209.

TROSTER, Roberto L. 2004. "Conspiração de bancos". Folha de São Paulo, São Paulo, 26/03/2004.

WEBER, M. 1995. Economie et société. Paris: Presses Pocket. 2 vol.

WOODS Jr., M. 2000. "Fads and fashions in management: the case of ERP". Revista de Administração de Empresas, 40(3):8-17.

ZELIZER, Viviana. 1979. Morals and markets: the development of life insurance in the United States. New York: Columbia University Press. 
Resumo

O texto pretende sustentar a existência de um modo financeiro de dominação na sociedade brasileira do início do século XXI. Para tanto, ele sugere uma cronologia para as transformações recentes da cultura econômica brasileira e mobiliza evidências em várias esferas: (i) sobre o sucesso da retórica que justifica as altas taxas de juros ali existentes, que seriam o resultado da desorganização da sociedade brasileira; (ii) sobre a propagação da governança corporativa, que é cada vez mais considerada o método correto de se gerir e avaliar organizações que se querem modernas; (iii) sobre a lógica da crítica direta à dominação financeira, que tenta personificá-la em indivíduos "exemplares". Nos três casos, a proeminência dos argumentos que sustentam os pontos de vista das finanças, vistos como positivos no quadro sugerido pela cronologia, são contrapostos às dificuldades da sua crítica, que é associada às suas polaridades negativas.

Palavras-chave: Cultura econômica, Sociologia econômica, Sociologia das finanças, "Financeirização", "Spread" bancário, Governança corporativa

\section{Abstract}

The article argues for the existence of a financial mode of domination in Brazilian society at the start of the 21st century. In support of this claim, it provides a chronology of the recent transformations in Brazilian economic culture and draws evidence from various spheres: (i) on the success of the rhetoric justifying the continuance of high interest rates in the country, supposedly a response to the disorganization of Brazilian society; (ii) on the propagation of corporate governance, increasingly advocated as the ideal method for managing and evaluating 'modern' organizations; (iii) on the logic adopted by the explicit critique of financial domination, which attempts to personify the phenomenon in the form of 'exemplary' individuals. In all three cases, the pre-eminence of the arguments sustaining the financial viewpoint - seen as positive within the ideological framework of the proposed chronology - are contrasted with the difficulties faced by its critique, associated with its negative poles.

Key words: Economic culture, Economic sociology, Financial sociology, Financialization, Bank spread, Corporate governance 